\title{
Best Interests of the Child in Finnish Legislation and Doctrine: What Has Changed and What Remains the Same?
}

\author{
Hannele Tolonen, Sanna Koulu and Suvianna Hakalehto
}

The best interests of the child is both internationally and nationally accepted as the most central, recurrent concept in modern legislation on childhood as well as in judicial praxis in matters concerning children and their legal status. The paramountcy of the best interests of the child is well established in child law and the concept has received wide attention in jurisprudence. Internationally, the best interests standard has been emphasised in the Convention on the Rights of the Child (CRC) and developed in the legal discussion on its provisions. Despite the lack of a specific provision on the best interests of the child in the European Convention of Human Rights (ECHR), the concept has also been developed in the jurisprudence of the European Court of Human Rights (ECtHR). ${ }^{1}$

In the Finnish legislation, the concept of best interests has been present from the early 2oth century. Today, the principle is central for example in legislation concerning parental responsibility, adoption, paternity, child welfare, social welfare and immigration law. ${ }^{2}$ However, throughout the 20 th century the concept of best interests has been employed mostly in substantive legislation. There is no specific mention of the best interests of the child in the Constitution itself. While the best interests of children are not specifically mentioned, it should be noted that several constitutional provisions can be seen to

1 See eg Handbook on European law relating to the rights of the child (European Union Agency for Fundamental Rights and Council of Europe 2015) 30-31.

2 Act on Child Custody and Right of Access (361/1983 laki lapsen huollosta ja tapaamisoikeudesta, Custody Act), Adoption Act (22/2012 adoptiolaki), Paternity Act (11/2015 isyyslaki), Child Welfare Act (417/2007 lastensuojelulaki), Social Welfare Act (1301/2014 sosiaalihuoltolaki), and Aliens Act (301/2004 ulkomaalaislaki).

(C) HANNELETOLONEN, SANNA KOULUAND SUVIANNA HAKALEHTO,2020 | DOI:10.1163/9789004382817_010 
reflect similar dimensions of the concept that are expressed in the CRC, such as treating children as individuals. ${ }^{3}$

Despite the widespread adoption of the principle in legislation, the UN Committee on the Rights of the Child has given Finland feedback for not understanding its importance. The Committee has also noted that the principle has not been implemented systematically in legislation and in courts. ${ }^{4}$ This implies that the understanding of the principle rooted in Finnish legal system is perhaps still not equivalent to the Committee's interpretation of the principle.

There are also diverging viewpoints within the Finnish literature on the role of the principle of the best interests of the child and on the importance of international and human rights provisions. For example, Nieminen has emphasised the conceptual connection between best interests and constitutional and human rights, arguing that the best interests are realised when children's constitutional and human rights are realised. ${ }^{5}$ On the other hand, Helin has pointed out that the concept of best interests had strong roots in the substantive family law of the 1980s, arguing that the constitutional substance on the concept is meagre. ${ }^{6}$

The openness of the interpretation of the concept also gives rise to debate. The contested and debated nature of the principle of best interests reflects important tensions in children's legal position and family and child policy. Firstly, the best interests principle has been criticized for having been interpreted too narrowly as only promoting the protection of children as vulnerable minors, and calls have been made to include the participation of the child more clearly in the assessment of his or her best interests. ${ }^{7}$ Secondly, the principle can be adopted in favour of a number of political stances regarding children and families. When the parliament restricted the right to early childhood education and care from full-time to part-time for children whose parent is staying at home,

3 See also Merike Helander, 'Utvecklingsbehov i den finländska lagstiftningen om barn' (2018) Nordisk Administrativt Tidsskrift nr. 1, 5, 7-9.

4 UN Committee on the Rights of the Child, Concluding observations: Finland (20 June 2011) $\mathrm{CRC} / \mathrm{C} / \mathrm{FIN} / \mathrm{CO} / 4$ para 27 .

5 Liisa Nieminen, 'Lasten perus- ja ihmisoikeussuojan ajankohtaisia ongelmia' (2004) Lakimies 591,621 .

6 Markku Helin, 'Perusoikeuksilla argumentoinnista', in Tero Iire (ed), Varallisuus, vakuudet ja velkojat:Juhlajulkaisu Jarmo Tuomisto 1952 - 9/6 - 2012 (University of Turku, Faculty of Law 2012). On the discussion, see also Liisa Nieminen, Perus-ja ihmisoikeudet ja perhe (Talentum 2013).

7 The UN Committee on the Rights of the Child notes succinctly that 'there can be no correct application of article 3 if the components of article 12 are not respected', see General Comment No. 12 (2009) The right of the child to be heard (1 July 2009) CRC/C/GC/12 para 74. 
the best interests concept was used in public debate not merely advocating for children's rights but also to promote the interests of parents as well as professionals in early childhood education and care. ${ }^{8}$ In these discussions, the concept can sometimes seem inconsistent, as the legal meanings intertwine with other interpretations.

In this paper, we wish to make sense of these interpretations and tensions in the Finnish context. We discuss how the principle of promoting the child's best interests gained ground in Finnish 2oth century legislation and examine the arguably crucial change that has taken place since the 1980s: the best interests of the child is increasingly interpreted in light of providing for the child's human rights and the rights of a child. We also examine whether a 'constitutionalisation' of this principle might be taking place. To this end we analyse current research, legislative work and case law, focusing especially on parental responsibility, child protection, immigration law and education. We pay particular attention to the material from the early 1980s, when the best interests principle was strengthened in a large legislative reform. After that, we move on to discuss the development from the 1990s - when the Constitution was renewed - to the present day. Last, we illustrate the current situation with some examples of the national legislation and its recent development and case law.

\section{The Best Interests Principle in the Past and in the Present}

2.1

The Historical Roots of the Principle

In Finnish legislation, national statutory provisions on the best interests of the child (lapsen etu, barnets bästa) have long preceded the current Constitution and CRC. The concept is mentioned in the adoption and matrimonial legislation from the 1920's, as well as in the first Child Welfare Act (1936). An early example of discussion on the concept can be found in Melander's dissertation on parental responsibility that was published in $1939 .{ }^{9}$

During the 1970's and the early 1980's, the aim to advance individual children's best interests by means of legislation gained more ground in the significant reform of legislation on children's person and family relations, where children's equality and participation were acknowledged in a rather modern way. These child law reforms can be said to have transformed the principle into

8 Suvianna Hakalehto and Toomas Kotkas, 'Subjektiivinen päivähoito-oikeus - sosiaalioikeutta, lapsioikeutta vai molempia?' (2005) Lakimies 1040-1063.

9 Ilmari Melander, Lapsen huollosta: Yksityisoikeudellinen tutkimus 1 (Suomalainen Lakimiesyhdistys 1939). 
a cornerstone of national legislation. ${ }^{10}$ In 1983 , the aim of advancing the child's interests became the cornerstone of the 'twin statutes': Custody Act and Child Welfare Act.

According to the Custody Act, which is still in force, any decision on parental responsibility must be made in accordance with the best interests of the child." The purpose of child welfare and child protection measures was to guarantee the quality of care. Similar provisions also came to apply in adoption and in implementing individual decisions and agreements on parental responsibility. In CRC article 3 , the best interests are famously stated to be $a$-instead of the primary consideration ${ }^{12}$ while in the above-mentioned Finnish legislation the principle is, at least on the surface, meant to be decisive. ${ }^{13}$

The concept of the best interests of the child became a subject of a lively discussion in the Finnish legal doctrine on children's family relations. ${ }^{14}$ In the aftermath of the legislative reform, Savolainen analysed the different aspects of the concept in light of the new custody legislation in detail, making references to psychological literature as well as to the international discussion..$^{15}$ One of the most profound changes was the turn from the previous ideal of a sole caretaker to a new ideal of joint custody. This shift took place relatively early in Finland, as was stated by Kurki-Suonio in a dissertation on changing legal interpretations of the best interests of the child in divorce or separation..$^{16}$ In 2006, Auvinen concluded the earlier discussion on the best interests of the child in a

10 See eg Government Proposals HE 224/1982 vp 4-6 and HE 13/1983 vp 8-9. For discussion, see also Matti Savolainen, Lapsen huolto ja tapaamisoikeus (Suomen Lakimiesliiton Kustannus 1984).

11 Custody Act section 10 subsection 1.

12 See, for example, Sharon Detrick, A Commentary on the United Nations Convention on the Rights of the Child (Martinus Nijhoff Publishers 1999) 91.

13 See eg the Finnish Supreme Court case кко 2003:126 in which the court states that according to section 10 of the Custody Act: 'all matters concerning custody and visiting rights of the child are decided on the basis of the child's best interests, regardless of whether parents agree or disagree on the matters at hand' (translation here).

14 Also researchers on social work have been active in studying topics around the best interests of the child. See, for example, Maritta Törrönen (ed), Lapsen etu ja viidakon laki (Lastensuojelun keskusliitto 1994).

15 Savolainen (n 10).

16 Kirsti Kurki-Suonio, Äidin hoivasta yhteishuoltoon: lapsen edun muuttuvat oikeudelliset tulkinnat - Oikeusvertaileva tutkimus (Suomalainen Lakimiesyhdistys 1999). In the dissertation, Finnish discussion was compared with that in Sweden, Germany, England and California. It is stated that the preference of joint custody was first adopted in a Californian reform on 1980. Finland and Sweden followed shortly thereafter, in 1983. On the English summary, see ibid 566. Personal relations and contact with both parents are emphasised for example in the later adopted CRC, article 9. 
way that reflected the widening dimensions and openness of the concept. The definition given in the dissertation on custody proceedings includes societal, psychological, cultural and moral dimensions. The best interests are described as both communal and individual. ${ }^{17}$

During recent years, the discussion on the principle of the best interests of the child and its importance in legislative work and court practice has continued in the Finnish jurisprudence. ${ }^{18}$ In a doctoral dissertation examining children's rights, it is common to include a special chapter dedicated to the best interests principle. ${ }^{19}$

\subsection{Best Interests in Light of Children's Fundamental and Human Rights}

The 199os brought a change in Finnish doctrine, as the CRC and the ECHR were ratified and implemented nationally, and human rights considerations became increasingly influential for legal decision-making. The understanding of the best interests of the child was still rooted in substantive legislation, but its interpretations started drawing on treaty obligations ${ }^{20}$ and, slowly, ECtHR case law. In 1995, the previous Constitution was renewed, adding provisions on fundamental rights (969/1995). These provisions were strongly influenced by human rights instruments, which brings similarity to their content, despite the conceptual differences. ${ }^{21}$

17 Maija Auvinen, Huoltoriidat tuomioistuimissa: sosiaalitoimi selvittäjänä, sovittelijana, asiantuntijana (Suomalainen Lakimiesyhdistys 2006) 203.

18 See, for example, Annika Parsons, The best interests of the child in asylum and refugee procedures in Finland (Ombudsman for Minorities, publication 5, 2010); Virve-Maria de Godzinsky, Lapsen etu ja osallisuus hallinto-oikeuksien päätöksissä (Oikeuspoliittinen tutkimuslaitos 2014); Suvianna Hakalehto, 'Lapsen edun arviointi korkeimman oikeuden perheoikeudellisissa ratkaisuissa' (2016) Defensor Legis 427-455; Milka Sormunen, "In All Actions Concerning Children"? Best Interests of the Child in the Case Law of the Supreme Administrative Court of Finland' (2016) 24 IJCR, 155-184.

19 See Henna Pajulammi, Lapsi, oikeus ja osallisuus (Talentum 2014) 181-203; Sanna Koulu, Lapsen huolto-ja tapaamissopimukset (Lakimiesliiton Kustannus 2014) 308-315; Hannele Tolonen, Lapsi, perhe ja tuomioistuin: Lapsen prosessuaalinen asema huolto- ja huostaanotto-oikeudenkäynnissä (Suomalainen Lakimiesyhdistys 2015) 74-98; VirveMaria Toivonen, Lapsen oikeudet ja oikeusturva: lastensuojeluasiat hallintotuomioistuimissa (Alma Talent 2017) 79-118.

20 See eg Liisa Nieminen, Lasten perusoikeudet (Lakimiesliiton kustannus 1990) and Liisa Nieminen 2013 (n 6) 305. Human rights provisions were also increasingly, although sporadically, applied in case law. See eg the Finnish Supreme Court decision Kко 1996:151, in a case related to international child abduction.

21 See Heikki Karapuu, 'Perusoikeuksien käsite ja luokittelu' in Pekka Hallberg and others, Perusoikeudet (WSOYpro 2011) 67. 
However, the constitutional reform did not include the concept of the best interests in the list of fundamental rights. This meant that even after the reform, the concept of best interests continued to develop in the light of human rights obligations more than based on constitutional rights. In the Constitution, the concept of best interests is still not mentioned. On the other hand, it is important not to overstate the significance of this omission, as children's rights and the CRC were specifically considered in the reform. ${ }^{22}$ The equal treatment of children was added to the list of the fundamental rights, reflecting the wording of the CRC: 'Children shall be treated equally and as individuals and they shall be allowed to influence matters pertaining to themselves to a degree corresponding to their level of development. ${ }^{23}$ Children's wellbeing and personal development were also included in the provision on social security, where the support to families and others responsible for providing for children is highlighted. ${ }^{24}$

According to the constitutional provision on protection of basic rights and liberties, the public authorities shall also guarantee the observance of human rights. ${ }^{25}$ When the constitutionality of legislative proposals is supervised in the parliament, their relation to international human right treaties is also assessed. ${ }^{26}$

In the recent discussion, the effects of the international conventions on the concept of the best interests have become more visible. The importance of the CRC has been made explicit. ${ }^{27}$ References to the provisions of this convention

22 A reference to the CRC was made in the preparatory works. Hallituksen esitys eduskunnalle perustuslakien perusoikeussäännösten muuttamisesta (HE 309/1993) 44-45. It has been pointed out that children's constitutional rights have earlier roots. See Nieminen 2004 (n 5) 592.

23 The Constitution of Finland 731/1999 (Suomen perustuslaki) section 6(3). An unofficial translation of Constitution is available at <https://www.finlex.fi/en/laki/kaannokset/1999/ en19990731_20111112.pdf> accessed 2 April 2019.

24 Nowadays in the Constitution, section 19 subsection 3. On emphasis on the family in the preparatory works see Perustuslakivaliokunnan mietintö n:o 25 hallituksen esityksestä perustuslakien perusoikeussäännösten muuttamisesta (PeVM 25/1994) 10. See also Perustuslakivaliokunnan lausunto (PeVL 30/2009 vp) hallituksen esityksestä laeiksi lastensuojelulain, vankeuslain 4 ja 2 luvun sekä tutkintavankeuslain 2 luvun 5 §:n muuttamisesta.

25 Section 22.

26 Section 74. The sections mentioned in this paragraph and other features of the system are also discussed in S Hakalehto, 'Constitutional Protection of Children's Rights in Finland', this volume, chapter 4; S Koulu, 'Children's Right to Family Life in Finland: A Constitutional Right or a Side Effect of the "Normal Family"?', this volume, chapter 17; H Tolonen, 'Children's Right to Participate and Their Developing Role in Finnish Proceedings, this volume, chapter 12.

27 See, for example, Markku Helin, 'Perheoikeuden siveellinen luonne' (2004) Lakimies $1244,125^{2}$. 
and, increasingly, to the Committee's general comments have become common in the later doctrine. The ECHR also plays a role in the discussion. ${ }^{28}$ Even though the convention does not contain a specific provision on the best interests of the child, the concept has been developed in the jurisprudence of ECtHR, where it has been discussed in light of the provisions of the CRC. ${ }^{29}$ It has been pointed out that the effective supervisory mechanism of the ECHR has underlined its importance also when children are concerned. ${ }^{30}$

These human rights provisions point out that a child's best interests must be determined in the context of his or her close relations, especially in relations with the child's family members. This aspect can clearly be seen in the text of the CRC, where close relations and the procedural rights of family members are protected by separate provisions, for example, in articles 9 and 18. In this sense, the umbrella of the best interests can be seen to encompass family relations in the convention. ${ }^{31}$

In the case law of the ECtHR, the discussion on the best interests of children has often taken place in the cases where the focus has been on questions concerning protection of family life (article 8). ${ }^{32}$ It should be noted that protection of family relations has formed an interesting, twofold relation with the concept of the best interests. On the one hand, it is generally in accordance with children's best interests to keep their family relations as intact as possible. On the other hand, in cases of negligence or violence the individual child's best interests can be seen to require that a family relation be restricted. ${ }^{33}$ Thus a decision on taking a child in care has seldom been considered to breach the

28 See, for example, Liisa Nieminen 2004 (n 5) 591, 594; Koulu (n 19) 67; Tolonen (n 19) 41; Milka Sormunen, 'Lapsen etu Euroopan ihmisoikeustuomioistuimen ratkaisukäytännössä' in Suvianna Hakalehto and Virve Toivonen (eds), Lapsen oikeudet lastensuojelussa (Kauppakamari 2016) 308.

29 See, for example, Nieminen 2013 (n 6) 344.

$30 \quad$ Nieminen 2004 (n 5 ) 594.

31 See also John Tobin, 'Fixed Concepts but Changing Conceptions: Understanding the Relationship Between Children and Parents under the CRC' in Martin D. Ruck, Michele Peterson-Badali and Michael Freeman (eds), Handbook of Children's Rights: Global and Multidisciplinary Perspectives (Routledge 2017) 53, 65: 'Instead of pitting the rights of parents against those of children, the CRC offers a relational rather than individualistic conception of rights ...' (emphasis added).

32 The relation of these two principles is examined later in this volume. See eg Koulu 2019 (n 26).

33 See, for example, A.E.L. $v$ Finland App no 59435/10 (ECtHR, 10 December 2013) para 6o. On the Finnish discussion on this aspect in light of the recent ECtHR case law see Tolonen (n 19) 93; Sormunen (n 28) 328. See also Sami Mahkonen Lastensuojelu ja laki (3rd ed, Edita Publishing 2010) 131. 
article 8 rights, ${ }^{34}$ but the authorities have an obligation to facilitate the reunification of the family in a reasonable way. ${ }^{35}$

The decisions on taking into care bring up an important conceptual division in the concept of the best interests: the concept relies on an understanding of what children's best interests are generally, while it also needs to account for an individual child's best interests in the specific circumstances of the case. ${ }^{36}$ Since the 199os, children's individual treatment has been acknowledged in the Constitution, while the best interests principle has traditionally been strongly connected to safeguarding the welfare of the child. ${ }^{37}$ The dual aspect of the best interests is widely acknowledged in recent discussion. ${ }^{38}$ Koulu has noted that both conceptions of the best interests standard are present in Finnish case law, and their sometimes uneasy co-existence can show tensions in our understanding of children's legal standing. ${ }^{39}$ In a similar vein, Hakalehto has found that the Supreme Court examines four main elements in assessing the best interests of the child in family law cases: i.e. securing the development of the child, maintaining relationships to both parents, paying attention to the views of the child and factors concerning the execution of the decision. ${ }^{40}$

Originally, the best interests of the child were linked mainly to the child protection, custody and maintenance, and adoption. ${ }^{41}$ The 1983 Custody Act connected the principle firmly with the child's individual situation and circumstances. ${ }^{42}$ Since then, children's own, individual input has been more clearly included in the definition of the concept of the best interests. In the

34 However, see the discussion on case $K$. and T. $v$ Finland [GC] App no 25702/94 (12 July 2001) below in 3.2 .

35 Finnish handbooks and commentaries on ECtHR case law are one crucial channel through which human rights praxis is adopted in national legal reasoning. For some examples, see eg Matti Pellonpää and others, Euroopan ihmisoikeussopimus (6th ed, Alma Talent 2018) and Päivi Hirvelä and Satu Heikkilä, Ihmisoikeudet: Käsikirja EIT:n käytäntöön (Alma Talent 2017). On international discussion, see for example Frédéric Sudre, Droit européen et international des droits de l'homme (13e ed, Presses Universitaires de France 2016) 770.

36 See Matti Mikkola and Jarkko Helminen, Lastensuojelu (Karelactio 1994) 21, where this division is discussed in light of the Child Welfare Act of 1983.

37 Pajulammi 2014 (n 19) 188.

38 See for example Pajulammi 2014 (n 19); Tolonen 2015 (n 19); Toivonen 2017 (n 19).

39 Koulu (n 19).

40 Hakalehto (n 18) 427-455.

41 Suvianna Hakalehto 'Lapsen oikeudet lapsen oikeuksien sopimuksessa' (2011) Defensor Legis 515 . On the international discussion, see Claire Breen, The Standard of the Best Interests of the Child: A Western Tradition in International and Comparative Law (Kluwer 2002).

See Savolainen (n 10) 116. 
earlier discussion, the concept of child's best interests can be described as foremostly based on objective grounds. The best interests could be construed by an outside observer looking at the circumstances. In the later discussion, more subjective stances on the concept have emerged. ${ }^{43}$

In line with the constitutional provision and the more detailed approach of the international conventions and their interpretations, the importance of children's participation when their best interests are determined has also gained ground in the Finnish legislation and discussion..$^{44}$ Early on, children's wishes were considered separate from their best interests, but this understanding is perhaps giving way to a more integrated approach. In light of the CRC, it is indeed doubtful whether a decision could be considered to be in accordance with the best interests of the child if sufficient attention has not been paid to the child's views and opinions. ${ }^{45}$

In the later Finnish legal research, the challenges of using the best interests principle have been emphasised. ${ }^{46} \mathrm{An}$ issue here is that the criteria used for assessing the best interests of the child are shaped by the perspectives of different professions, such as social workers and doctors and the police, which may lead to inconsistent interpretations.$^{47}$ Calls for a more precise formulation of the concept of the best interests have continued in the recent discussion. ${ }^{48}$ One approach is to connect the principle more firmly with the rights-based view based on the provisions of the CRC. The rights-based view of this principle has also been emphasised by the Children's Ombudsman in statements concerning legislative proposals ever since the office was established in 2005 .

In recent case law, Supreme Court has mentioned children's constitutional rights in the context of their best interests. The Court has stated that holders of parental responsibility must take into account the restrictions that are

43 Here, the terms objective and subjective are used in a similar way that can be found in for example Swedish preparatory works. See Statens offentliga utredningar 1997:116, section 6.2.1.

44 The concept of participation and the procedural aspects are discussed in more detail by one of the authors in another article in this volume. See Tolonen (n 26).

45 See UN Committee on the Rights of the Child, General Comment No. 14 (2013) on the right of the child to have his or her best interests taken as a primary consideration (art. 3, para 1 ) (29 May 2013) CRC/C/GC/14, para 43. See also Nieminen 2004 (n 5) 691; Pajulammi (n 19) 190.

46 See, for example, Toivonen (n 19) 107-109 and Koulu (n 19) 308-315.

47 Päivi Hirvelä, Rikosprosessi lapsiin kohdistuvissa seksuaalirikoksissa (WSOYpro 2006) 234235 . The vagueness of the best interests principle might result from the culture of reasoning: the elements of the best interests of the child are not always clearly stated and it might remain unclear which criteria has been taken into account. 
possibly set by children's constitutional rights and to aim for decisions that realise children's overall best interests. ${ }^{49}$ In effect, the best interests of the child were conceptualised in light of constitutional rights as well as human rights obligations. If this line of thinking were to become more prevalent, it would require paying attention not only to the concrete welfare of the child or to international human rights instruments like the CRC but also to the constitutional rights provisions in the Constitution.

The Best Interests Principle in Recent Legislative Work and Case Law

\subsection{Parental Responsibility}

According to the Custody Act (361/1983), the purpose of custody (huolto) includes ensuring the welfare and balanced development, good care and ageappropriate supervision of the child. Education, environment, understanding and affection are also mentioned among the criteria, as well as supporting the child's growth towards independence and responsibility. Corporal punishment is specifically prohibited. ${ }^{50}$ In the discussion, these provisions have been interpreted to reflect the idea of children having constitutional rights, despite the lack of a specific reference in the preparatory works. ${ }^{51}$

A recent reform in legislation, which will come in force in December 2019, brings several changes in the Custody Act and some related provisions. In the preparatory works, the constitutional provision on children is mentioned and international human rights provisions are discussed. ${ }^{52}$

49 See the criminal law case кко 2018:81 (on publishing filmed material on child protection measures) where a reference was made to an earlier Supreme Court case кко 2008:93 (on male circumcision).

$5^{\circ}$ Section 1 reads like this, according to an unofficial translation: 'The purpose of child custody is to ensure the welfare and balanced development of a child in accordance with the child's individual needs and wishes. The purpose is also to secure a close and affectionate relationship in particular between the child and his or her parents. (2) A child must be ensured good care and upbringing as well as supervision and protection appropriate for his or her age and stage of development. A child should be brought up in a secure and stimulating environment and receive an education that corresponds to his or her inclinations and wishes. (3) A child must be brought up with understanding, security and affection. A child must not be subdued, corporally punished or treated offensively in any other way. The growth of a child towards independence, responsibility and adulthood must be supported and encouraged.' <https://www.finlex.fi/en/laki/kaannokset/1983/ en19830361.pdf $\geq$ accessed 9 December 2018.

$51 \quad$ See Nieminen 2004 (n 5) 593-594.

52 Government proposal HE 88/2018 vp. Hallituksen esitys eduskunnalle laiksi lapsen huollosta ja tapaamisoikeudesta annetun lain muuttamisesta ja eräiksi siihen liittyviksi 
Many of the modifications can be seen to strengthen the goals of more individualised determination of a child's best interests. Firstly, the goal of protecting children against possible risks will be more clearly expressed in the provision on the purpose of custody. An obligation to protect the child from all physical and mental violence, mistreatment and abuse was added in section 1. According to the preparatory works, the purpose is to realise the obligations that can be derived from CRC article $19 .{ }^{53}$ During the parliamentary work, a related modification was also made to the provision on the grounds for decision on parental responsibility (huolto ja tapaamisoikeus, custody and visitation). The parents' ability to protect children against all violence was added among the criteria. ${ }^{54}$

Secondly, more flexibility will be introduced to material decisions on children's living and access arrangements. The possibility of alternating residence (vuoroasuminen, växelvis boende) is acknowledged in the provisions. It may be agreed or given a court order that a child lives alternately with two parents or a parent and another person who has parental responsibility. ${ }^{55}$ Another change towards a more individualised determination of children's best interests is that a court may make an order on a child's contact with other relatives and close persons, if their relation with the child is comparable to that of a parent and child. In the preparatory works, references are made to ECtHR case law on article 8.56

The provision on veto power that children have when decisions or agreements on parental responsibility or contact are enforced is also slightly modified, calling for a more individual determination of the situation. According to the current legislation, children's right to refuse enforcement is expressed in absolute terms, leaving little leeway for individual considerations. ${ }^{57}$ In $C . v$

laeiksi. In preparation of the proposal, a wide range of interest groups from different fields of society were heard. The discussion and comments illustrate the differing interpretations children's best interests can be given, depending on the point of view.

53 HE 88/2018 vp (n 52) 18.

54 Custody Act (190/2018) section 1 subsection 2; section 10 subsection 3. See also Legal Affairs Committee Report 12/2018 vp. Lakivaliokunnan mietintö hallituksen esityksestä eduskunnalle laiksi lapsen huollosta ja tapaamisoikeudesta annetun lain muuttamisesta ja eräiksi siihen liittyviksi laeiksi (LaVM 12/2018 vp).

55 See Custody Act (190/2018) section 7; section 7b; section 9 subsection 2.

$5^{6}$ Custody Act (190/2018) subsection 9c. On the preparatory works, see HE 88/2018 vp (n 52) 13-14.

57 Enforcement may not take place against the will of a child who has attained 12 years or against the will of a younger child if they are considered sufficiently mature (laki lapsen huoltoa ja tapaamisoikeutta koskevan päätöksen täytäntöönpanosta 619/1996 section 2). 
Finland (2006), ECtHR criticised the Finnish Supreme Court for giving an impression that 12- and 14-year-old children could decide the outcome of a parental responsibility case. ${ }^{58}$ According to the modified provision, the factors possibly affecting children's opinion are to be given consideration when assessing their refusal. ${ }^{59}$

A tendency to take children's best interests better into account in the more general procedural framework is also gaining momentum. In the recent discussion, the need for suitable, tailored approaches in decision-making has been called for to ensure the best interests of the individual child. All parental responsibility conflicts are not the same. In Auvinen's analysis of parental responsibility cases, standard 'equal' conflicts were differentiated from more complicated cases: psychosocial conflicts, where parents' abilities may be compromised, and pathological conflicts, where conflict level is heightened. ${ }^{60}$ If risk factors for the child's wellbeing are in sight, a more thorough procedural approach and additional safeguards may be needed to protect the best interests than in a situation where all available alternatives can be deemed safe. ${ }^{61}$

An example of new, more tailored approach to parental responsibility proceedings is a special court mediation, which was legislated in 2014. The mediation takes place in district courts with the help of an expert mediator. ${ }^{62}$ According to the recently reformed provisions in the Custody Act, such experts are also introduced in cases that are not mediated but disputed in court. A court may appoint an expert (asiantuntija-avustaja) to help to hear a child a childfriendly way. Besides helping the judge, the expert may also meet the parents. ${ }^{63}$

\subsection{Child Protection}

The objective of child welfare services (child protective services, lastensuojelu) is intertwined with the goal of safeguarding and promoting the best interests

58 C. v Finland App no 18249/o2 (9 May 20o6). In more detail, see Tolonen (n 26 ).

59 Laki lapsen huoltoa ja tapaamisoikeutta koskevan päätöksen täytäntöönpanosta (191/ 2018) section 2 subsection 2.

6o Auvinen (n 17) 254 .

61 Tolonen (n 19) 36o. On this standpoint in light of the Swedish system see Anna Kaldal, Parallella processer: En rättsvetenskaplig studie av riskbedömningar i vårdnads- och LVUmål (Jure Förlag 2010) 169 .

62 Custody Act chapter 3 a (315/2014). See also Kirsikka Salminen, 'Mediation and the Best Interests of the Child from the Child Law Perspective' in Anna Nylund, Kaijus Ervasti and Lin Adrian (eds), Nordic Mediation Research (Springer 2018) 209, 212.

63 Custody Act (190/2018) section 15 a. See also HE 88/2018 vp (n 52). The provision aims to strengthen children's possibilities for participation. The aim is also reflected in the changes on children's personal hearing by the courts and by the social authorities. The aspects of participation are discussed in Tolonen (n 26). 
of the child. In the current Child Welfare Act, ${ }^{64}$ the objective of the act is 'to protect children's rights to a safe growth environment, to balanced and wellrounded development and to special protection'. In the same vein, it is 'first and foremost the interests of the child that must be taken into account' in providing child welfare services (Child Welfare Act, section 4). ${ }^{65}$ The fact that the best interests of the child are an important justification for state intervention $^{66}$ also leads to a fundamental tension for child welfare services. The best interests of the child are a key concern in carrying out child welfare measures, but many of those measures can also affect the child's life in negative ways by e.g. limiting the child's contact with her family or by placing restrictions on her enjoyment of other constitutional rights. ${ }^{67}$

This tension between safeguarding the child's best interests and intervening in her daily life has been recognized in Finnish legislative work early on ${ }^{68}$ and it underlies many of the ECtHR decisions regarding Finland. An important strand of case law concerns the separation of the child from her family via decisions on taking the child into care. Thus, for example, the case $K$. and T. $v$ Finland $[\mathrm{GC}](2001)^{69}$ involved several emergency care orders, care orders, and restrictions on access that were examined separately in the light of article 8 of ECHR. No violation was found for the normal care orders or the restrictions on access, and they were considered to be in service of the authorities' primary task of protecting the children's best interests. ${ }^{70}$ At the same time, the Court

64 Child Welfare Act (417/2007, lastensuojelulaki). An unofficial translation of the Act is available at <https://www.finlex.fi/fi/laki/kaannokset/2007/en20070417_20131292.pdf $\geq$ accessed 24 August 2018.

65 The complete list in section 4(2), according to an unofficial translation, is the following: '1) balanced development and wellbeing, and close and continuing human relationships; 2) the opportunity to be given understanding and affection, as well as supervision and care that accord with the child's age and level of development; 3 ) an education consistent with the child's abilities and wishes; 4) a safe environment in which to grow up, and physical and emotional freedom; 5) a sense of responsibility in becoming independent and growing up; 6) the opportunity to become involved in matters affecting the child and to influence them; and 7) the need to take account of the child's linguistic, cultural and religious background.'

66 Cf Handbook on European law relating to the rights of the child (n 1$) 99$.

67 In Finnish jurisprudence this tension, and the relation between the governance of families and the protection of children, has been examined eg by Eeva Valjakka in her doctoral dissertation Vain lakiko lasta suojelee? (University of Turku 2016) 191-196.

68 Government proposal HE 13/1983 vp (n 10) 5 .

$69 \quad K$. and T. $v$ Finland [GC] App no 25702/94 (12 July 2001).

70 See also Olsson $v$ Sweden (No. 1 ) App no 10465/83 (24 March 1998), where the placement decisions had eg significantly restricted family life due to geographical distance. 
noted that the Finnish authorities had overstepped the margin of appreciation especially with regard to the extremely harsh measure of taking a new-born into care based on an emergency care order, and had not taken proper steps to reunite the family. The reasoning of the Court shows the importance of procedural safeguards. In addition, children's rights considering the ECHR also require the state parties to make sure that social services are available to protect children and that effective remedies exist for negligence or other shortcomings in the provision of those services. ${ }^{71}$

In domestic terms, the case law of ECtHR was a significant influence on the current Child Welfare Act. The current act dates from 2007 and was based on thorough reforms that aimed at bringing the legislation up to date regarding Finland's international treaty obligations. The constitutional rights reform of 1995 and the implementation of the CRC were a key element in the need for reform, and the case law of ECtHR was analysed carefully regarding involuntary care orders in particular. ${ }^{72}$ The provisions of the ECHR are reflected e.g. in the procedural provisions in chapters 14 (Administrative court proceedings) and 15 (Appeals) of the reformed Act ${ }^{73}$ and the preparatory works specifically examine the case law of the Court. ${ }^{74}$ Meanwhile, the provisions of the CRC were highlighted in connection with safeguarding children's agency and participation rights in the reformed Act. ${ }^{75}$

Interestingly, the best interests of the child are not directly based on human rights obligations in the preparatory works preceding the reform. ${ }^{76}$ Instead, the best interests standard is presented more as a measure of the child's day-to-day well-being than a treaty obligation, perhaps drawing from the established tradition of evaluating the best interests of the child in family law contexts. In comparison with the weight given to human rights treaties in the reform of procedural provisions and children's participation, the concept of the best interests of the child remains more flexible.

71 See eg $Z$ and others $v$ the United Kingdom [GC] App no 29392/95 (10 May 2001 ).

72 See Government proposal HE 252/2006 vp Hallituksen esitys lastensuojelulaiksi ja eräiksi siihen liittyviksi laeiksi, chapter 2.1.2.

73 See HE 252/2006 vp (n 72 ).

74 HE 252/2006 vp (n 72) 44-45.

75 HE 252/2006 vp (n 72).

76 See eg HE 252/2006 vp (n 72) 117, where section 4 on determining the child's best interests is discussed very briefly. CRC is mentioned but not really utilized in formulating the content of the section. 
The reform of 2007 was comprehensive, and in addition to the changes drawing directly on human rights considerations, it introduced several improvements in its practical implementation. Some of the improvements are not immediately obvious, though, nor is there always an explicit connection to the underlying treaty obligations. For example, section 32 , on identifying the network of people close to the child, is hidden away in chapter 6 on procedural rules. The section provides that before a child's placement away from home 'it is necessary to investigate what opportunities there are for the child to live with the parent with whom the child does not primarily reside, with the relatives or with other persons close to the child, or for these parties otherwise to participate in supporting the child.' The section goes on to note that 'A matter concerning the child's accommodation or placement location must always be resolved in a manner consistent with the child's interests.' There is an implied connection between a child's best interests and family relations, but the preliminary works focus on the child's well-being and do not include references to specific treaty obligations or general comments. ${ }^{77}$

The developments of the past decade also show in domestic case law. Unlike cases on child custody and contact, which belong to the Supreme Court (korkein oikeus), child welfare cases are part of the ambit of the Supreme Administrative Court (korkein hallinto-oikeus). The Supreme Administrative Court has adopted a human-rights-sensitive approach early on in its reasoning, and the recent case law reflects this to a notable extent. ${ }^{78}$ For example, in its decision KHO 2004:121, the Supreme Administrative Court examined whether and when open care orders might be shown to be insufficient to safeguard the best interests of the child, and bases its decision on the provisions of the CRC as well those of the ECHR and national legislation. ${ }^{79}$

However, the picture on the grassroots level is not quite as rosy as the wellfounded reasoning of the Supreme Administrative Court might suggest. Child welfare services are chronically underfunded, and the dual role of social services (as services aiming to provide for children and their families' well-being, versus as decision-makers on sensitive topics such as access) makes for friction in the provision of services. The praxis of the Parliamentary Ombudsman (Eduskunnan oikeusasiamies) has noted several issues that affect the

$77 \quad$ HE 252/2006 vp (n 72) 15 o.

78 However, see Sormunen (n 18) where the author notes that the consideration of the best interests principle depends largely on the issue in question.

79 The court referred specifically to CRC articles 3, 9 and 20, and to article 8 of the ECHR. The court also mentioned the case law of ECtHR and especially the decision in Couillard Maugery v France App no 64796/o1 (1 July 2004). 
constitutional rights of children and families, and one key area in this praxis is whether the best interests of the child are safeguarded appropriately. The most recent yearly report lists shortcomings in child welfare services as one of ten pressing issues in the realization of human and constitutional rights in Finland.$^{80}$ Many of the shortcomings the report calls out are related to the need for more resources and more effective oversight for child welfare services. The report also emphasises the constitutional rights of children in care, especially institutional care, and the importance of system-level integration of mental health care and child welfare services.

\subsection{Education}

3.3.1 Basic Education

In Finland, it is still not common to see school as an area where children should be noticed as independent right holders regardless of their status according to the Constitution of Finland. When the Finnish Basic Education Act ${ }^{81}$ was prepared, the CRC was mentioned at the list of the human rights treaties, but no further attention was paid to children's rights. ${ }^{82}$ Instead the Act mostly highlights the duties of pupils. ${ }^{83}$ The same goes with the Act of General Secondary Education ${ }^{84}$ and the Vocational Education and Training Act. ${ }^{85}$

Disciplinary methods are one key area where human rights obligations should be considered in education, and, in 2013, amendments were made to the education legislation concerning them. ${ }^{86}$ The preliminary works refer to the CRC but the role of the Convention in school legislation is not discussed closely. However, participation rights which are an essential element of the

8o See Parliamentary Ombudsman's yearly report 2017,113 . The report is available in Finnish and Swedish at <https://www.oikeusasiamies.fi/fi/toimintakertomukset $\geq$ and $<$ https://www.oikeusasiamies.fi/sv/web/guest/verksamhetsberattelser $\geq$ accessed 24 August 2018.

81 Perusopetuslaki, 628/1998.

82 Government proposal HE 86/1997 vp. Hallituksen esitys eduskunnalle koulutusta koskevaksi lainsäädännöksi, 13.

83 The Finnish Basic Education Act sets three duties for the students: the duty to attend classes, the duty to behave correctly and the duty to complete the tasks diligently (section 35). On children's rights and duties at school, see Suvianna Hakalehto, Oppilaan oikeudet opetustoimessa (Lakimiesliiton Kustannus 2012).

84 Lukiolaki, 714/2018.

85 Laki ammatillisesta koulutuksesta, 531/2017.

86 Government proposal HE 66/2013 vp. Hallituksen esitys eduskunnalle laeiksi perusopetuslain, lukiolain, ammatillisesta koulutuksesta annetun lain, ammatillisesta aikuiskoulutuksesta annetun lain ja kunnan peruspalvelujen valtionosuudesta annetun lain 41 ja 45 §:n muuttamisesta. 
best interests of the child were introduced on a general level with new sections. Thus, section 47a of the Basic Education Act obligates schools to promote participation of pupils and to examine views of parents and students. However, the general right of the child to participate in his or her own matter is not embedded in school legislation except in a few specific situations. ${ }^{87}$

There is no general provision on the best interests of the child in the Basic Education Act. ${ }^{88}$ This is probably one of the reasons best interests of the child have not been referred to in court praxis concerning school. The scarcity of the case law also plays a part, as there have been no school-related cases concerning children's rights in the Supreme Court. There are few cases in the Supreme Administrative Court, mainly on the right to free school transportation. The CRC or the best interests of the child have not been referred to in the reasoning of the school-related cases of the Supreme Administrative Court. ${ }^{89}$

The invisibility of the best interest principle in case law concerning children's rights at school probably follows from the lack of provision on the best interests of the child in school legislation. In the recent report of the Ministry of Education and Culture on preventing bullying at school one of the proposals is to add a provision concerning the best interests of the child to the Basic Education Act. ${ }^{90}$

Parliamentary Ombudsman refers regularly to the CRC in the cases concerning school. Ombudsman has stated that the best interests of the child must be a primary consideration in all decisions concerning arranging the teaching of an individual child. ${ }^{91}$

In Finland, school inspection was abolished in the early 199os. No independent authority exists in charge of monitoring how children's rights are realised

87 According to the Basic Education Act the student must be heard before the decision on the special needs support is made (section 17 , subsection 3 ) and before some of the disciplinary methods are used (section 36 a, subsection 1 ). According to section 18 , subsection 1 of the School Welfare Act (1287/2013; oppilas- ja opiskelijahuoltolaki) student's views must be given due weight according to his or her age and development.

88 Best interests of the child is included in section 17 of the Basic Education Act. No referral to CRC can be found in the preliminary work concerning the provision. Government proposal HE 109/2009 vp. Hallituksen esitys eduskunnalle perusopetuslain muuttamiseksi.

89 See KHO 2004:99, KHO 2006:10, КHO 2006:79, КHO 2006:8о, КнO 2009:130 and КHO 2013:127. On Supreme Administrative Court's argumentation based on the best interests of the child see Sormunen (n 18) 155-184.

90 See 'Kiusaamisen ehkäisy sekä työrauhan edistäminen varhaiskasvatuksessa, esi-ja perusopetuksessa sekä toisella asteella. Loppuraportti' Opetus- ja kulttuuriministeriön julkaisuja 2018:16.

91 See, for example, EOA 12.7 .2015 , Dnro $1633 / 4 / 14$ on the right of the child to get special support for learning. 
in schools. National evaluations of education concentrate on learning outcomes rather than the legality of the activities and operation of schools. One of the main problems concerning children's rights and realising the best interests of the child in education seems to be the lack of the systematic and rightsbased approach in legislation and in the everyday life at school. ${ }^{92}$

\subsubsection{Early Childhood Education and Care}

In contrast with the sparse provisions on children's rights in school settings, the legislation on early childhood education and care has recently been reformed in line with the obligations of the CRC. The new act on Early Childhood Education and Care ${ }^{93}$ entered into force in September 2018. The preliminary work of the Act begins by citing the general principles of the CRC and listing the contents of the articles 3, 12, 18, 23 and $28 .{ }^{94}$ The preliminary works refer to the latest Concluding Observations to Finland by the UN Committee on the Rights of the Child where the Committee recommends that the State party drafts a new general act on early childhood care and education, strengthening the child rights perspective. ${ }^{95}$

There is a provision on the best interests of the child in the Act (section 4), according to which, the best interests of the child must be given a primary consideration when planning, arranging and making decisions on early childhood education and care. The section 20 , subsection 1, obligates to find out children's opinions and wishes when planning, arranging and evaluating early childhood education and care.

Similarly, with school settings, early childhood education and care may also involve everyday situations in which children's personal liberty and integrity are being limited, for example, when children must be prevented from doing something that is harmful to them or to the other children. However, contrary to the school legislation, the legislator has chosen not to regulate these situations in early childhood education and care. This raises the question if the constitutional rights of children under seven years old are considered somehow minor compared to the older children or if limiting constitutional rights

92 See Suvianna Hakalehto-Wainio, 'The Best Interests of a Child in School' (2014) Family Law \& Practice 105-112 and Niina Mäntylä, 'Effective Legislation Regarding School Bullying? The Need for and Possibility of Law Reform in Finland' (2018) 18 Education Law Journal 186-198.

93 Varhaiskasvatuslaki, 540/2018.

94 Government proposal HE 40/2018 vp. Hallituksen esitys varhaiskasvatuslaiksi ja siihen liittyväksi lainsäädännöksi.

95 Concluding observations of the Committee on the Rights of the Child: Finland (n 4) para 56 . 
in certain situations in day care is in general regarded to be in the best interest of the child. The matter was not discussed in the Parliament during the process of passing the Early Childhood Education and Care Act. ${ }^{96}$

\subsection{Immigration}

In the immigration law, children are mostly involved in matters concerning asylum, family reunification and deportation. The Finnish Aliens Act ${ }^{97}$ includes several sections concerning minors. According to section 6, in any decision issued under the Act concerning a child under eighteen years of age, special attention shall be paid to the best interests of the child and to the circumstances related to the child's development and health. ${ }^{98}$

Best interests of the child can have significance when considering requirements for means of support when issuing a residence permit. According to the Aliens Act, section 39, subsection 1 issuing a residence permit requires that the alien does have secure means of support. In individual cases, an exemption may be made from this requirement if there are exceptionally weighty reasons for such an exemption or if the exemption is in the best interest of the child. ${ }^{99}$ The recent case law shows that the threshold to make an exemption based on the best interests of the child is high. The reasons have related to the health of the child. 100

There are several referrals to the CRC on the preparatory works of the Aliens Act. Despite of the difference in wording between CRC article 3 ('shall be a primary consideration') and Aliens Act section 6 ('special attention shall be paid'), it seems clear that legislator has aimed the section to be in the conformity with the CRC. ${ }^{101}$ According to the Government proposal, the child's best interests should

96 See Suvianna Hakalehto, Lapsioikeuden perusteet (Alma Talent 2018) 271-272.

97 Ulkomaalaislaki, 310/2004. The Finnish Aliens Act is founded on conflicting aims: to promote a controlled immigration and to provide international protection respecting fundamental and human rights the former aim having gained more and more weight in recent years.

98 The role of the best interests of the child in the Aliens Act differs from for example child welfare and child custody where the best interests of the child is a decisive factor (Child Welfare Act s 40 ss 2; Child Custody Act s 10 ss 1). Aliens Act s 6 ss 3 obligates authorities to handle cases concerning minors with urgency.

99 According to the Aliens Act section 146, when considering refusal of entry, deportation or prohibition of entry and the duration of the prohibition of entry, account must be taken of the facts on which the decision is based and the facts and circumstances otherwise affecting the matter as a whole. Particular attention must be paid to the best interests of the children and the protection of family life.

$100 \quad$ KHO 2014:51.

101 Government proposal HE 28/2003 vp 8-10. Hallituksen esitys eduskunnalle ulkomaalaislaiksi ja eräiksi siihen liittyviksi laeiksi. Administration Committee Report HaVM 4/ 
be considered as a whole taking into account the child's individual needs, wishes and opinions. It is also mentioned in the proposal that the person deciding has to clarify what is in the best interests of the child in question. ${ }^{102}$

The Finnish Immigration Service is the first instance to decide on applications concerning asylum, residence permit, family reunification and other immigration law related issues. The Committee on the Rights of the Child has issued a general comment on treatment of unaccompanied and separated children outside their country of origin (CRC/GC/2005/6). ${ }^{103}$ This comment as well as general comments 12 and 14 are referred to on the guidelines concerning handling and decision-making in the Finnish Immigration Service. ${ }^{104}$

NGO s advocating for asylum-seekers' and children's rights have criticized the Finnish Immigration Service because of the lack to make an individual decision concerning each child when they are in Finland with their guardian. The status of a child as an independent rights-holder supports individual decisionmaking even when the child is in Finland with a family member. ${ }^{105}$

The best interests of the child are referred to in most of the Supreme Administrative Court immigration-related cases. This results from the above cited provision of the Aliens Act, according to which special attention shall be paid to the best interests of the child. The CRC has been mentioned in one-third of the immigration law related decisions of the Supreme Administrative Court. ${ }^{106}$ It is possible to recognize certain factors that the Supreme Administrative Court

2004 vp, 8. Hallintovaliokunnan mietintö hallituksen esityksistä (HE 28/2003 vp, HE 151/2003 vp) ulkomaalaislaiksi ja eräiksi siihen liittyviksi laeiksi.

102 Government proposal HE 28/2003 vp (n 101) 9.

103 According to the general comment, the State parties should respect the best interests of the child in their territory when providing assistance for unaccompanied minors and looking after their affairs at every stage of the process. 'A determination of what is in the best interests of the child requires a clear and comprehensive assessment of the child's identity, including her or his nationality, upbringing ethnic, cultural and linguistic background, particular vulnerabilities and protection needs'. The views and wishes of the unaccompanied or separated child must be taken into consideration.

104 Maahanmuuttovirasto: Lapsen asian käsittely ja päätöksenteko Maahanmuuttovirastossa. MIGDno/2013/1037. 23.4.2015. According to the study from 2010 the best interests of the children are not being assessed when a minor asylum seekers arrives in Finland accompanied by guardians. This conclusion is based on the finding that decisions do not include anything on the interests of the children or, even if they are mentioned, it is not disclosed how the matter was taken into consideration. See Parsons (n 18) 95-96.

105 See Suvianna Hakalehto and Katariina Sovela, 'Lapsen etu ja sen ensisijaisuus ulkomaalaisasioita koskevassa päätöksenteossa' in Toomas Kotkas, Heikki Kallio and Jaana Palander (eds), Ulkomaalaisoikeus (Alma Talent 2018) 407-445.

106 See Hakalehto and Sovela (n 105). See also Milka Sormunen, 'Ulkomaalaislain muutokset lasten perus- ja ihmisoikeuksien näkökulmasta' (2017) Lakimies 387-408. 
takes into account when assessing the best interests of the child. ${ }^{107}$ The Court considers if the decision will lead to separating the child from the safe and familiar environment. ${ }^{108}$ Related to this is the stability of the circumstances and the capability of the child to adjust to new conditions. ${ }^{109}$ Also, the length of the time the child has lived with the parent and the reasons for separation are taken into account as is the factual bond between the child and the parent.110 A lot of attention is paid to the matters concerning health of the child or the parent ${ }^{111}$ and considering if the circumstances of the country of origin or country where the child is living will threaten safety, health or development of the child. ${ }^{112}$ Financial interests are often mentioned. ${ }^{113}$

In 2016, the legal status of minor asylum-seekers deteriorated in a significant way when amendments were made to the Finnish Aliens Act. The application of the requirement or means of support related to family reunification was broadened which can be seen problematic for the rights of the child. This has brought criticism on the legislator for understanding the best interests of the child in an overly narrow way. ${ }^{114}$

\section{4}

\section{Conclusions}

One of our key findings is that both subtle and more profound changes have taken place in the content and dimensions of the concept of the best interests of the child, maybe more so than is visible at the level of terminology. The concept of the best interests is more varied and nuanced today than in the past, and international human rights instruments and their interpretations have played an important role in this development. The domestic constitutional provisions have not yet quite followed suit, having been somewhat less visible in the discussion. However, the constitutional dimensions of the concept are reflected in the recent case law, where children's constitutional rights have been discussed in the context of decision-making on their best interests. Attention has been paid not only to the international human rights instruments such as the CRC but also to the Constitution.

\footnotetext{
107 See Hakalehto and Sovela (n 105) 407-445.

108 KHO 2013:97, KHO 2016:75.

109 KHO 2O10:18, KHO 2012:47.

110 KHO 2009:86, КнО 2014:162.

111 KHO 2O10:18, KHO 2017:6.

112 KHO 2O13:23, КHO 2017:73, КНO 2017:74.

113 KHO 2003:92, KHO 2010:17, KHO 2014:50.

114 See Sormunen (n 106) 408.
} 
The role of the international human rights obligations is increasingly important in the interpretation of the best interests of the child. The CRC and its implementation in Finnish legislation are significant in principle, and references to the convention and to the committee's general comments are becoming commonplace. However, there may be a risk that the implementation of the CRC obligations is fragmented among different fields of law and that the convention provisions do not always inform the interpretation of national legislation on the grassroots level. Here, the European Convention of Human Rights provides an interesting point of comparison, as the complaints mechanism and especially the case law of the ECtHR may help national courts engage more fully with the convention obligations in practice. It may be that the interpretation of the best interests of the child will continue to be influenced by the ECtHR case law, which presents a model for considering the role of the $\mathrm{CRC}$ rights in the context of legal reasoning.

One of the most central changes is a shift of focus to protecting close relationships of the child and the importance of preserving them. In the light of the human rights provisions, children's best interests must be determined in this context. In this sense, the umbrella of the best interests can be seen to include family relations. In the case law of the ECtHR, the best interests of children are often discussed in the light of protection of family life (article 8). In the praxis, the protection of family relations has formed an interesting, twofold relation with the concept of best interests. Generally, preserving children's family relations is considered to be in accordance with their best interests. However, the individual child's best interests may require that a family relation be restricted.

More generally, a clear focus has been placed on children's individual status and their input in determining the content of their best interests, which are both acknowledged in the Constitution. This aspect has gained a foothold in recent legislation, bolstered by the constitutional provision on treating children as individuals. Possible risk factors affecting child's welfare have also gained increasing attention along with the importance of non-discrimination and the needs of marginalised and at-risk groups. One can draw some parallels between these lines of discussion, but inherent conflicts are also present.

\section{References}

Administration Committee Report HaVM 4/2004 vp. Hallintovaliokunnan mietintö hallituksen esityksistä (HE 28/2003 vp, HE 151/2003 vp) ulkomaalaislaiksi ja eräiksi siihen liittyviksi laeiksi. 
Auvinen M, Huoltoriidat tuomioistuimissa: sosiaalitoimi selvittäjänä, sovittelijana, asiantuntijana (Suomalainen Lakimiesyhdistys 2006).

Breen C, The Standard of the Best Interests of the Child: A Western Tradition in International and Comparative Law (Kluwer 2002).

Committee on the Rights of the Child, Concluding observations: Finland (20 June 2011) $\mathrm{CRC} / \mathrm{C} / \mathrm{FIN} / \mathrm{CO} / 4$.

Committee on the Rights of the Child, General Comment No. 12 (2009) The right of the child to be heard (1 July 2009) CRC/C/GC/12.

Committee on the Rights of the Child, General Comment No. 14 (2013) on the right of the child to have his or her best interests taken as a primary consideration (art. 3, para 1 ) (29 May 2013) CRC/C/GC/14.

Constitutional Law Committee Report PeVM 25/1994 vp. Perustuslakivaliokunnan mietintö hallituksen esityksestä perustuslakien perusoikeussäännösten muuttamisesta.

Constitutional Law Committee Statement PeVL 30/20o9 vp. Perustuslakivaliokunnan lausunto hallituksen esityksestä laeiksi lastensuojelulain, vankeuslain 4 ja 20 luvun sekä tutkintavankeuslain 2 luvun 5 §:n muuttamisesta.

Detrick S, A Commentary on the United Nations Convention on the Rights of the Child (Martinus Nijhoff Publishers 1999).

de Godzinsky V-M, Lapsen etu ja osallisuus hallinto-oikeuksien päätöksissä (Oikeuspoliittinen tutkimuslaitos 2014).

Government proposal HE 224/1982 vp. Hallituksen esitys eduskunnalle laeiksi lapsen huollosta ja tapaamisoikeudesta ja holhouslain muuttamisesta sekä niihin liittyvien lakien muuttamisesta.

Government proposal HE 13/1983 vp. Hallituksen esitys eduskunnalle lastensuojelulaiksi.

Government proposal HE 309/1993 vp. Hallituksen esitys eduskunnalle perustuslakien perusoikeussäännösten muuttamisesta.

Government proposal HE 86/1997 vp. Hallituksen esitys eduskunnalle koulutusta koskevaksi lainsäädännöksi.

Government proposal HE 28/2003 vp. Hallituksen esitys eduskunnalle ulkomaalaislaiksi ja eräiksi siihen liittyviksi laeiksi.

Government proposal HE 252/2006 vp. Hallituksen esitys eduskunnalle lastensuojelulaiksi ja eräiksi siihen liittyviksi laeiksi.

Government proposal HE 109/2009 vp. Hallituksen esitys eduskunnalle perusopetuslain muuttamiseksi.

Government proposal HE 66/2013 vp. Hallituksen esitys eduskunnalle laeiksi perusopetuslain, lukiolain, ammatillisesta koulutuksesta annetun lain, ammatillisesta aikuiskoulutuksesta annetun lain ja kunnan peruspalvelujen valtionosuudesta annetun lain 41 ja 45 §:n muuttamisesta. 
Government proposal HE 40/2018 vp. Hallituksen esitys eduskunnalle varhaiskasvatuslaiksi ja siihen liittyväksi lainsäädännöksi.

Government proposal HE 88/2018 vp. Hallituksen esitys eduskunnalle laiksi lapsen huollosta ja tapaamisoikeudesta annetun lain muuttamisesta ja eräiksi siihen liittyviksi laeiksi.

Hakalehto S, 'Constitutional Protection of Children's Rights in Finland' in Trude Haugli and others (eds), Children's Constitutional Rights in the Nordic Countries, (Brill 2019).

Hakalehto S, 'Lapsen edun arviointi korkeimman oikeuden perheoikeudellisissa ratkaisuissa' (2016) Defensor Legis 427.

Hakalehto S, Lapsioikeuden perusteet (Alma Talent 2018).

Hakalehto S and Kotkas T, 'Subjektiivinen päivähoito-oikeus - sosiaalioikeutta, lapsioikeutta vai molempia?' (2015) Lakimies 1040.

Hakalehto S and Sovela K, 'Lapsen etu ja sen ensisijaisuus ulkomaalaisasioita koskevassa päätöksenteossa' In Toomas Kotkas, Heikki Kallio, Jaana Palander (eds), Ulkomaalaisoikeus (Alma Talent 2018) 407.

Hakalehto-Wainio S, 'Lapsen oikeudet lapsen oikeuksien sopimuksessa' (2011) Defensor Legis 510.

Hakalehto-Wainio S, Oppilaan oikeudet opetustoimessa (Lakimiesliiton Kustannus 2012).

Hakalehto-Wainio S, 'The Best Interests of a Child in School' (2014) Family Law \& Practice 103 .

Handbook on European law relating to the rights of the child (European Union Agency for Fundamental Rights and Council of Europe 2015).

Helander M, 'Utvecklingsbehov i den finländska lagstiftningen om barn' (2018) Nordisk Administrativt Tidsskrift nr. 1, 5 .

Helin M, 'Perheoikeuden siveellinen luonne' (2004) Lakimies 1244.

Helin M, 'Perusoikeuksilla argumentoinnista', in Tero Iire (ed), Varallisuus, vakuudet ja velkojat:Juhlajulkaisu Jarmo Tuomisto 1952 - 9/6 - 2012 (University of Turku, Faculty of Law 2012) 11.

Hirvelä P, Rikosprosessi lapsiin kohdistuvissa seksuaalirikoksissa (WSOYpro 2006).

Hirvelä P and Heikkilä S, Ihmisoikeudet: Käsikirja EIT:n käytäntöön (Alma Talent 2017).

Kaldal A, Parallella processer: En rättsvetenskaplig studie av riskbedömningar ivårdnadsoch LVU-mål (Jure Förlag 2010).

Karapuu H, 'Perusoikeuksien käsite ja luokittelu' in Pekka Hallberg and others, Perusoikeudet (WSOYpro 2011).

Koulu S, 'Children's Right to Family Life in Finland: A Constitutional Right or a Side Effect of the "Normal Family"?' in Trude Haugli and others (eds), Children's Constitutional Rights in the Nordic Countries (Brill 2019).

Koulu S, Lapsen huolto-ja tapaamissopimukset (Lakimiesliiton Kustannus 2014). 
Kurki-Suonio K, Äidin hoivasta yhteishuoltoon: lapsen edun muuttuvat oikeudelliset tulkinnat - Oikeusvertaileva tutkimus (Suomalainen Lakimiesyhdistys 1999).

Legal Affairs Committee Report LaVM 12/2018 vp. Lakivaliokunnan mietintö hallituksen esityksestä eduskunnalle laiksi lapsen huollosta ja tapaamisoikeudesta annetun lain muuttamisesta ja eräiksi siihen liittyviksi laeiksi (LaVM 12/2018 vp).

Maahanmuuttovirasto, Lapsen asian käsittely ja päätöksenteko Maahanmuuttovirastossa. MIGDno/2013/1037. 23.4.2015.

Mahkonen S, Lastensuojelu ja laki (3rd ed, Edita Publishing 2010).

Melander I, Lapsen huollosta: Yksityisoikeudellinen tutkimus 1 (Suomalainen Lakimiesyhdistys 1939).

Mikkola M and Helminen J, Lastensuojelu (Karelactio 1994).

Mäntylä N, 'Effective Legislation Regarding School Bullying? The Need for and Possibility of Law Reform in Finland' (2018) 18 Education Law Journal 186.

Nieminen L, Lasten perusoikeudet (Lakimiesliiton kustannus 199o).

Nieminen L, 'Lasten perus- ja ihmisoikeussuojan ajankohtaisia ongelmia' (2004) Lakimies 591.

Nieminen L, Perus-ja ihmisoikeudet ja perhe (Talentum 2013).

Pajulammi H, Lapsi, oikeus ja osallisuus (Talentum 2014).

Parliamentary Ombudsman's yearly report 2017.

Parsons A, The best interests of the child in asylum and refugee procedures in Finland (Ombudsman for Minorities, publication 5, 2010).

Pellonpää M and others, Euroopan ihmisoikeussopimus (6th ed, Alma Talent 2018).

Salminen K, 'Mediation and the Best Interests of the Child from the Child Law Perspective' in Anna Nylund, Kaijus Ervasti and Lin Adrian (eds), Nordic Mediation Research (Springer 2018) 209.

Savolainen M, Lapsen huolto ja tapaamisoikeus (Suomen Lakimiesliiton Kustannus 1984).

Statens offentliga utredningar 1997:116. Barnets Bästa i främsta rummet. FN:s konvention om barnets rättigheter i Sverige. Barnkommittéens huvudbetänkande (Socialdepartementet 1997).

Sormunen M, “"In All Actions Concerning Children”? Best Interests of the Child in the Case Law of the Supreme Administrative Court of Finland' (2016) 24 IJCR, 155.

Sormunen M, 'Lapsen etu Euroopan ihmisoikeustuomioistuimen ratkaisukäytännössä' in Suvianna Hakalehto and Virve Toivonen (eds), Lapsen oikeudet lastensuojelussa (Kauppakamari 2016) 308.

Sormunen M, 'Ulkomaalaislain muutokset lasten perus- ja ihmisoikeuksien näkökulmasta' (2017) Lakimies 387.

Sudre F, Droit européen et international des droits de l'homme (13e ed, Presses Universitaires de France 2016). 
Tobin J, 'Fixed Concepts but Changing Conceptions: Understanding the Relationship Between Children and Parents under the CRC' in Martin D. Ruck, Michele PetersonBadali and Michael Freeman, Handbook of Children's Rights. Global and Multidisciplinary Perspectives (Routledge 2017) 53.

Toivonen V-M, Lapsen oikeudet ja oikeusturva: lastensuojeluasiat hallintotuomioistuimissa (Alma Talent 2017).

Tolonen H, 'Children's Right to Participate and Their Developing Role in Finnish Proceedings' in Trude Haugli and others (eds), Children's Constitutional Rights in the Nordic Countries (Brill 2019).

Tolonen H, Lapsi, perhe ja tuomioistuin: Lapsen prosessuaalinen asema huolto- ja huostaanotto-oikeudenkäynnissä (Suomalainen Lakimiesyhdistys 2015).

Törrönen M (ed), Lapsen etu ja viidakon laki (Lastensuojelun keskusliitto 1994).

Valjakka E, Vain lakiko lasta suojelee? (University of Turku 2016). 